\title{
THE ASSESSMENT OF VEGETATION IN UNMANAGED NEMORAL FORESTS IN ZEMGALE
}

\author{
Dace Broka, Līga Liepa, Inga Straupe \\ Latvia University of Agriculture \\ liga.liepa@1lu.lv
}

\begin{abstract}
Zemgale geobotanical region historically was dominated by large broad-leaved forests, but last centuries the high anthropogenic pressure on these territories has reduced the area of these forests. In fragmented landscape small patches of natural broad-leaf forests are protected to preserve the forest structural features, which also function as habitats for rare and protected species. The aim of this study was to compare the natural broad-leaf forest habitats and structural elements and vegetation in woodland key habitats in production forests and protected areas (nature park 'Tērvete' and nature reserve 'Ukru gārša') in Zemgale. In total, 12 sample plots were established (the size of sample plot $0.1 \mathrm{ha}$ ) in Aegopodiosa forest type. In all sample plots forest structural features were measured and vegetation survey using Braun-Blanquet method was made. In this study, we found that average amount of dead wood varies between $78.7 \mathrm{~m}^{3} \mathrm{ha}^{-1}$ in woodland key habitats in production forests and $133.0 \mathrm{~m}^{3} \mathrm{ha}^{-1}$ special protected areas. Considerable amount of broad-leaf natural forests represented by nemoral species ( $50-58 \%$ of species richness), which corresponds to these forest type communities in the region.
\end{abstract}

Key words: Woodland key habitats, deciduous forest stands, forest vegetation, forest structural elements.

\section{Introduction}

Latvia is located in the hemiboreal zone - the contact zone of boreal coniferous forest and temperate broad-leaf forests (Krampis, 2011). Part of Latvian forests belong to the broad-leaved forest vegetation classes, where the dominant species is Fraxinus excelsior, Quercus robur and Tilia cordata, with other deciduous trees in admixture (Priedītis, 1999), sometimes also Scots pine (Ikauniece, 2013). The most important features for biodiversity are uneven age stand structure with large dimension trees, dead wood in various stages of decay, understorey dominated by decidous trees and shrubs, and the small proportion of Norway spruce (Priedītis, 1999). The gap dynamics is a common type of natural disturbance (Mežaka, 2009) where in open patches the development of first pioneer phase and broad-leaved tree species occurs (Ikauniece, 2013). Zemgale geobotanical region historically was dominated by large areas of broadleaved forests, but in last centuries human activities affected the area and reduced the area of these forests (Zunde, 1999). Zemgale is one of the oldest and most deforested Latvian regions where forests are currently fragmented and occupy about $10-12 \%$ from region's area (Tabaka, 2001). The ancient broad-leaved forests where replaced by deciduous pioneer species, for instance, Betula spp., Populus tremula, Alnus incana and A.glutinosa (Suško, 1997; Ek et al., 2002). Consequently, the dominant tree species changed the structure of understorey (Laiviņš et al., 2008; Laiviņš et al., 2014). Woodland key habitats (WKH) are characterized by habitat specialist species, indicator species and stand structural features (Ek et al., 2002; Lārmanis, Priedītis, \& Rudzīte, 2002). These relatively small forest areas with high ecological value are considered to be cost-effective biodiversity conservation tool in fragmented production forests (Timonen, 2011). The high valuable broad-leaved forests is protected habitat type in EU level (code: 9020*) (Auniňš, 2013).

The aim of this study was to compare forest stand structural elements and vegetation in broad-leaved $\mathrm{WKH}$ in production forests and formally protected areas in Zemgale.

The hypothesis of this study is that structural elements and vegetation in broad-leaved $\mathrm{WKH}$ is significantly different in production forests and formally protected areas.

This aim requires following study objectives:

1. to analyze structural elements (living trees and dead wood - snags, stems and downed log pieces) of broad-leaved WKHs;

2. to assess the vegetation of broad-leaved WKH (tree, shrub, herbaceous and moss layers);

3. to compare broad-leaved $\mathrm{WKH}$ in production forests and formally protected areas.

\section{Materials and Methods}

Study area. The study was conducted in Southern part of Zemgale geobotanical region. The data were collected in 2012 - 2014. Altogether 12 study sites were chosen for analysis. The sites are in Aegopodiosa forest type - four broad-leaf WKH in production forests, four - the natural park 'Tērvete' and four - the nature reserve 'Ukru gārša' (Figure 1).

The properties of each site were measured on a sample plot size $20 \times 50 \mathrm{~m}$ (size: $0.1 \mathrm{ha}$ ) with exposition S-N or SW-NE direction from stand edge to interior (Liepa \& Straupe, 2012). Each plot was divided into five sublots (zones) with respective distance from edge to core: $0-10 \mathrm{~m}\left(1^{\text {st }}\right), 10-20 \mathrm{~m}\left(2^{\text {nd }}\right)$, $20-30 \mathrm{~m}\left(3^{\text {rd }}\right), 30-40 \mathrm{~m}\left(4^{\text {th }}\right)$ and $40-50 \mathrm{~m}\left(5^{\text {th }}\right)$. The 


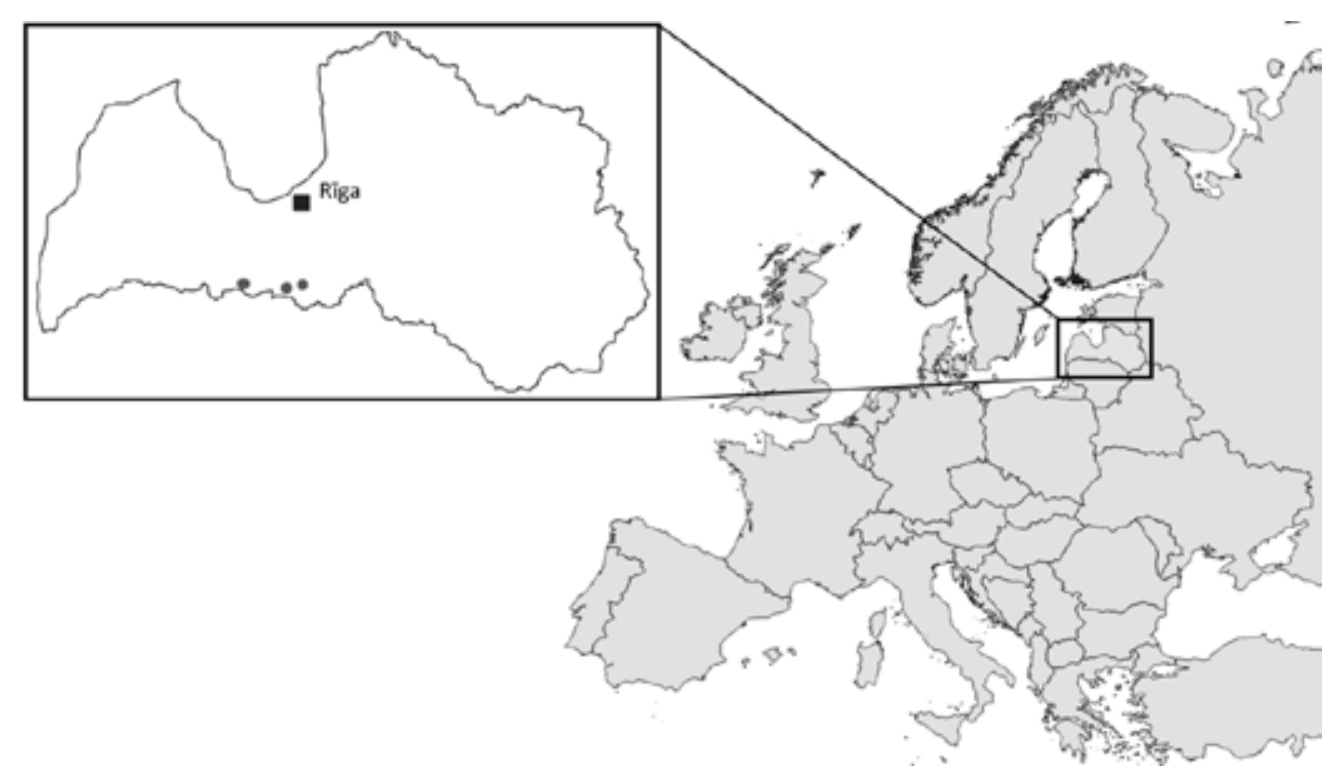

Figure 1. Location of the studied area in Southern Latvia, Zemgale geobotanical region.

stand structural features were measured in all sample plots $(20 \times 50 \mathrm{~m})$, but vegetation survey was done in the $1^{\text {st }}, 3^{\text {rd }}$ and $5^{\text {th }}$ zone, which respresents the plant composition in all vegetation layers.

Stand structural elements. All live trees and standing dead wood was measured at breast height $(\mathrm{DBH}, 1.3 \mathrm{~m})$ also downed dead logs and pieces (diameter $\geq 10 \mathrm{~cm}$ ) were measured. For each element, the tree species were recorded. Live tree trunk volumes were computed using a species specific volume functions (Liepa, 1996). The volumes of individual snags, stems and logs were computed using formulas by Liepa (1996). The decay stages were characterized for all dead wood according to Hunter (Neville \& Bastrup-Birk, 2006) where decay stage was determined using five classes: 1) dying recently before sampling, a knife penetrates less than $1 \mathrm{~cm}$ into bark; 2) fairly hard wood, a knife penetrates $1-3 \mathrm{~cm}$ into the wood; 3) soft wood, a knife penetrates over $3 \mathrm{~cm}$ into the wood; 4) wood soft throughout, a knife penetrates all the way; 5) wood almost decomposed and a hand penetrates throughout.

Vegetation survey. The Braun-Blanquet approach has been used to survey and describe plant communities: the total projective coverage of moss, herb, shrub and tree layers as well as coverage of each separate species was evaluated in each zone as percentage (\%): tree layer (E3) (tree species from height $7.0 \mathrm{~m}$ ), shrub layer (E2), (shrub and tree species at height from 0.5 to $7.0 \mathrm{~m}$ ), herb layer (E1) (including vascular plants, dwarf shrub, schrub and tree species up to height $0.5 \mathrm{~m}$ ) and moss layer (E0) (Liepa \& Straupe, 2012). The nomenclature for vascular plants follows Garvrilova \& Šulcs (1999) and that for mossess Ābolina, Piterāns \& Bambe (2015). For each separate species in herbaceous layer the constancy classes were described (Markov, $1965)$, which correspond to the index I $(<21 \%)$, II $(21 \%-40 \%)$, III $(41 \%-60 \%)$, IV $(61 \%-80 \%)$, V (81\% - 100\%) (Mueller-Dombois \& Ellenberg, 1974). The plant ecological groups were described for abiotic conditions according to Ellenberg (Ellenberg et al., 1992), seed and spore dispersal types and life forms according to Raunkiaer (База данных Флора сосудистых растений Центральной России).

Data processing. In this study, descriptive methods were used for data of vegetation (mean, standard error (SE) with confidence interval 95\%). A statistical distribution was assessed graphically. According to the results (symetrical distribution of data), parametrical methods were chosen. ANOVA test was used to estimate the significant variations between gradation classes and Tukey's HSD test. A risk level of 5\% (p $<0.05$ ) was used to define statistical significance (Arhipova \& Bāliṇa, 2006).

\section{Results and Discussion}

Stand structural elements. WKH structural elements are structures in forest, for example, living trees with various dimensions and dead wood, important for habitat specialist species (Ek et al., 2002; Timonen et al., 2010). We found significant differences $(p<0.05)$ in the volume of living trees: for broad-leaved WKHs in managed forests volume was on average $310.2 \mathrm{~m}^{3} \mathrm{ha}^{-1}$, and the largest portion of it was Populus tremula L. (55\%) - a pioneer species which colonises former broad-leaved stands with natural succession. In formally protected areas - the nature park 'Tērvete' and nature reserve 'Ukru gārša' - the volume of living trees was $321.4 \mathrm{~m}^{3} \mathrm{ha}^{-1}$ and $195.4 \mathrm{~m}^{3} \mathrm{ha}^{-1}$ respectively (made up by mostly Fraxinus excelsior L. - 48\% and 58\%) 


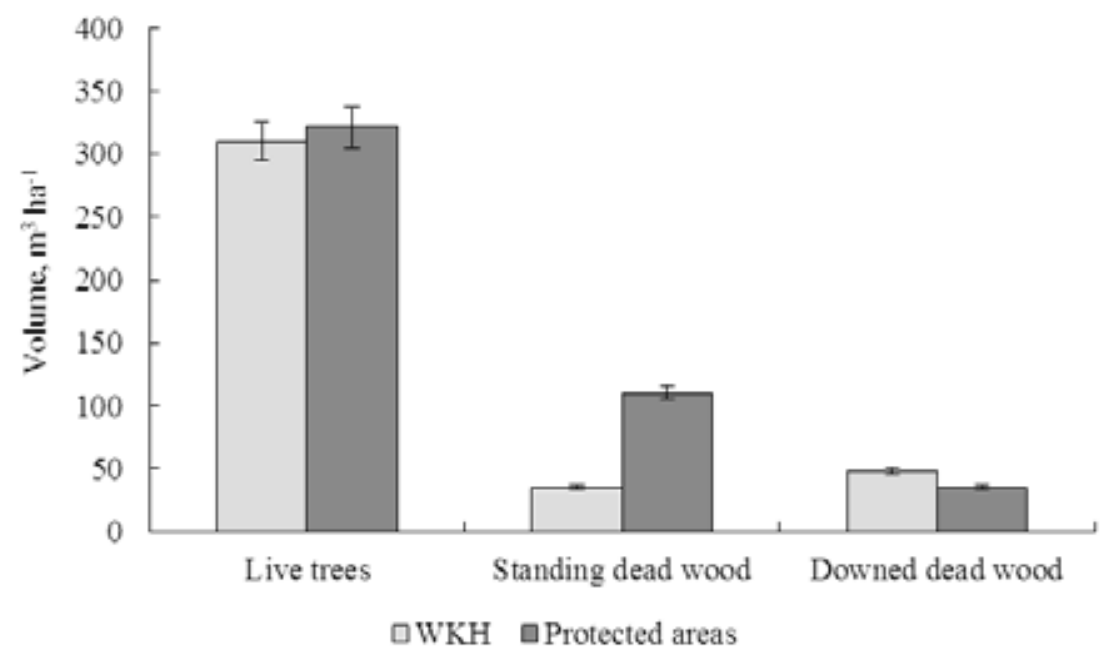

Figure 2. Diversity of forest stand structural elements. Values are means $\pm \mathrm{SE}$.

(Figure 2). In Eastern Europe and Latvia, stable are forest stands in which shade-tolerant tree species are dominant, for example, Fraxinus excelsior (Laivin̄š, 2014). Average volume of living trees is significantly lower in the nature reserve 'Ukru gārša', which is explained by increased dieback of Fraxinus excelsior due to pathogenic fungus Chalara fraxinea (Kenigsvalde et al., 2010; Pautasso et al., 2013).

In sample plots, we found dead wood types stumps, snags and pieces, and their volume in broadleaved WKH differs significantly $(\mathrm{p}<0.05)$ - in production forests dead wood volume reaches on average $78.7 \mathrm{~m}^{3} \mathrm{ha}^{-1}$, but in formally protected areas volume is larger - on average $133 \mathrm{~m}^{3} \mathrm{ha}^{-1}$. This is explained by natural dynamics in these forests - gap dynamics as well as with rapid dieback of Fraxinus excelsior trees. In production, forests dead wood volume is influenced also by the distance to populated places and the need for firewood by local inhabitants. Compared to the amount found in the Second cycle of Latvian National Forest inventory $\left(23.5 \mathrm{~m}^{3} \mathrm{ha}^{-1}\right)$, dead wood volume in WKHs in production forests is almost three times larger, and in protected areas - almost six times larger (Meža nozares attīstības novērtējums, 1990 - 2013.). The average volume of stumps, snags and downed logs and pieces is significantly different $(p<0.05)$ between broad-leaved WKHs in production forests and protected areas. In the nature reserve 'Ukru gārša', the volume of stumps is larger $\left(30.5 \mathrm{~m}^{3} \mathrm{ha}^{-1}\right)$, which is explained by recent dieback of ash trees. In the future stumps will form snags and pieces, thus securing the continuity of dead wood (Ek et al., 2002). However, the largest volume of stumps $\left(27.8 \mathrm{~m}^{3} \mathrm{ha}^{-1}\right)$ was found in WKHs in production forests. This is mostly due to the large proportion of Populus tremula in stands which have reached their biological age started to die or were damaged in windbreaks. Currently in Latvia standing dead wood volume is on average $9.1 \mathrm{~m}^{3} \mathrm{ha}^{-1}$ (Meža nozares attīstības novērtējums, 1990 - 2013.). In all study plots the largest portion of dead wood volume was made up by downed logs and pieces - on average $69 \%$ or $81.9 \mathrm{~m}^{3} \mathrm{ha}^{-1}$ (in average $14.4 \mathrm{~m}^{3} \mathrm{ha}^{-1}$ ) (Meža nozares attīstības novērtējums, 1990 - 2013.). The volume of dead wood pieces in broad-leaved WKHs in production forests was $41.9 \mathrm{~m}^{3} \mathrm{ha}^{-1}$, but in protected areas $-101.9 \mathrm{~m}^{3} \mathrm{ha}^{-1}$. Dead wood pieces on forest floor decompose relatively faster, and they in the short term are inhabited by larger number of organisms - insects, mosses, lichens, fungi (Bobiec et al., 2005). In broadleaved WKHs in production forests the majority of dead wood volume is $18-26 \mathrm{~cm}$ in diameter which characterizes semi-natural forests (Bobiec et al., 2005), but in protected forest it differs: in the nature reserve 'Ukru gārša' it is $20-32 \mathrm{~cm}$ but in nature park 'Tērvete' - $64 \mathrm{~cm}$. In dry forest stands, dead wood is relevant for biodiversity with a diameter of at least $25 \mathrm{~cm}$ (Auniņš, 2013). Also, a study on moss species diversity managed forests shows that a larger diameter of dead wood correlates with a higher number of dead wood requiring species (Madžule, Brūmelis, \& Tjarve, 2012). In broad-leaved WKHs in production forests strongly decayed dead wood (V stage of decay) was not found - this shows that the wood decay in these forests has started more recently (most common was dead wood at III stage of decay). In formally protected areas, dead wood was found at all five stages of decomposition that secures the continuity of dead wood and habitat for multiple organism groups (Blaser et al., 2013). Dead wood volume is being used as an indicator of biodiversity qualities; however, diversity of dead wood and occurrence at different stages of decay is also important (Lassauce et al., 2011). Furthermore, such forests are indicators of 


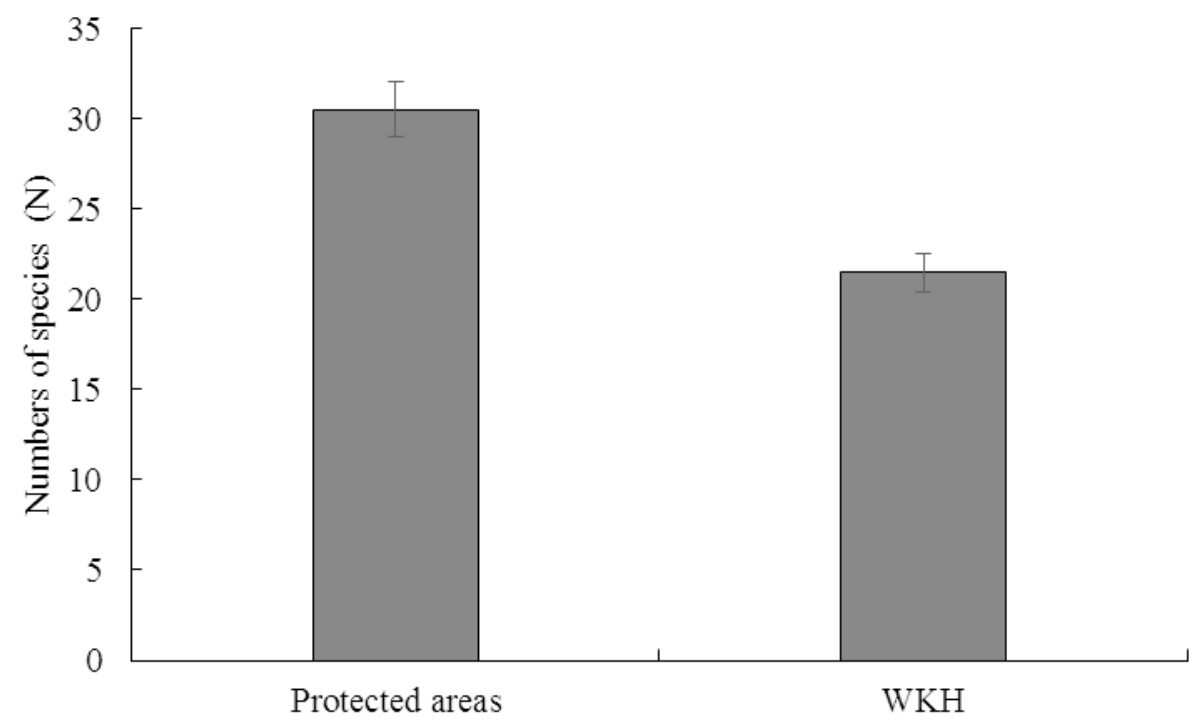

Figure 3. Numbers of species in protected areas and woodland key habitats (WKH). Values are means $\pm \mathrm{SE}$.

continuity (Bobiec et al., 2005; Stokland et al., 2012). Compared between WKHs in production forests and protected areas, a higher diversity of structural elements, environmental conditions and ecological niches is found in forests untouched by human activities (Brūmelis \& Jankovska, 2013).

Vegetation survey. In broad-leaved WKHs in production forests in total 50 vascular plant and moss species were found (seven tree, nine shrub, 24 vascular and nine moss species) - on average 30 species per study site. Broad-leaved WKHs in the nature park 'Tērvete' contained 42 species (seven tree, six shrub, 24 vascular and five moss species), bet the nature reserve 'Ukru gārša' - 56 plant species (seven tree, seven shrub, 33 vascular and nine moss species) - on average 33 species (Figure 3). Numbers of species by vegetation layers and projective coverage in WKHs in production and formally protected areas was not significantly different.

In all study plots, nemoral biome species ( $50-58 \%$ of the total number of species) were most common. In broad-leaved WKHs in production forests, four European broad-leaved forest habitat specialist species were found, but in WKHs in protected areas - six habitat specialist species; thus, we conclude that studied forests correspond to European broad-leaved forests. Hemiboreal zone in Latvia is characterized by mosaic-type patterns determined mostly by soil richness (Laiviňš, 2014). In the study plots, Fraxinus excelsior L. (at tree, shrub and herbaceous layers), Padus avium Mill., Corylus avellana L., Sorbus aucuparia L. (shrub layer), Rubus caesius L., Hepatica nobilis Mill., Oxalis acetosella L. and Paris quadrifolia L. (herbaceous layer) were most common species. In broad-leaved WKHs in production forests the largest projective coverage was made up by a shrub layer (45\%) (Padus avium, Lonicera xylosetum L.), but in protected areas - a herbaceous layer with Aegopodiosa forest type vascular species Aegopodium podagraria L., Anemone nemorosa L., Hepatica nobilis ( $45 \%$ and $40 \%$ respectively). Species number and projective coverage in moss layer is small in all study plots characteristic to this forest type. Here, the most commonspecies was Plagiomnium affine T.J. Kop. - characteristic to broad-leaved forests on rich mineral soils (Liepa et al., 2014). In all study sites, regeneration with Fraxinus excelsior was found, but in production forests it is hindered by a dense shrub layer. Plant communities of nemoral broad-leaved forests occur on rich soils, but if modifications of coniferous or broad-leaved plant communities are found, it demonstrates soil moisture and richness variability, anthropogenic actions or other environmental factors (Laiviňš, 2014). In all broad-leaved WKHs, perennial vascular plants or hemicryptophytes dominate $(39 \%)$, ornitochorous are most common ones (39\%), to a lesser degree (20\%) myrmecochores - mostly vernal plants which disperse with the help of ants as well as anemochorus plants (16\%), (Bumbura et al., 1967). Ecological variables for herbaceous layer in broad-leaved WKHs do not differ significantly $(\mathrm{p}>0.05)$. In production, the forests' herbaceous layer is characterized by halfshade conditions moderately warm and moist neutral soils, rich in nitrogen; however, in protected areas half-shade to half-light conditions, moderately moist to moist neutral soils, rich in nitrogen are common. Broad-leaved WKHs in production and formally protected forests differ, but production forests WKHs also contain the necessary diversity of structural elements and vegetation features. 


\section{Conclusions}

1. In general, in broad-leaved WKHs in production forests and formally protected areas the volume of living trees is not significantly different $(\mathrm{p}>0.05)$, dominated by respectively Populus tremula L. and Fraxinus excelsior $\mathrm{L}$. The difference is significant in the nature reserve 'Ukru gārša' where rapid Fraxinus excelsior dieback was found.

2. Broad-leaved WKHs are characterized by all types of dead wood - standing dead wood and downed $\log$ pieces. Their volume differs significantly: in total, in WKHs in production forests, it is almost three times larger, but in protected areas almost six times larger compared to the results of Second cycle of Latvian National Forest Inventory $-23.5 \mathrm{~m}^{3} \mathrm{ha}^{-1}$.

3. In broad-leaved WKHs, the average volume of stumps is significantly different that is explained by a rapid dieback of Fraxinus excelsior in protected areas forests.

4. In all broad-leaved WKHs pieces are the dominant type of dead wood (on average $69 \%$ or $\left.81.9 \mathrm{~m}^{3} \mathrm{ha}^{-1}\right)$.

5. Broad-leaved WKHs in production forests are dominated by dead wood with a diameter $18-26$ $\mathrm{cm}$ in four decay classes, but in protected areas forests $-32 \mathrm{~cm}$ and $64 \mathrm{~cm}$ diameter in five decay classes which is a sign of forest continuity.

6. In broad-leaved WKHs in production forests, vegetation is formed by on average 24 species, but in formally protected areas by 33 species on average. Species richness by vegetation layers and projective coverage does not differ significantly. Since the species of nemoral biome dominates $(50-58 \%)$, study plots correspond to European broad-leaved forests.

7. All broad-leaved WKHs were dominated by perennial vascular plants or hemicryptophytes $(39 \%)$ and ornitochorous plants were common (39\%).

8. Ecological variables for herbaceous layer in broad-leaved WKHs were not significantly different. In production forests, herbaceous layer is characterized by half-shade conditions moderately warm and moist neutral soils, rich in nitrogen; however, in protected areas half-shade to halflight conditions, moderately moist to moist neutral soils, rich in nitrogen are common.

\section{References}

1. Arhipova, I., \& Bāliṇa, S. (2006). Statistika ekonomikā un biznesāa (Statistics in Economics and Business). Rīga: Datorzinību centrs. (in Latvian).

2. Auniňš, A. (2013). European Union Protected Habitats in Latvia. Interpretation Manual. Auniņš A. (Eds.) Riga: Latvian Fund for Nature, Ministery of Environmental Protection and Regional Development.

3. Āboliņa, A., Piterāns, A., \& Bambe, B. (2015). Latvijas k̦ērpji un sünas (Lichens ad Mossess in Latvia). Taksonu saraksts. Salaspils: Latvijas Valsts mežzinātnes institūts Silava. (in Latvian).

4. Blaser, S., Prati, D., Senn-Irlet, B., \& Fischer, M. (2013), Effects of forest management on the diversity of deadwood - inhabiting fungi in Central Europen forests. Forest Ecology and Management, 304, pp. $42-$ 48. DOI: $10.1016 /$ j.foreco.2013.04.043.

5. Bobiec, A., Gutowski, J.M., Laudenslayer, W.F., Pawlaczyk, P., \& Zub, K. (2005). The Afterlife of a Tree. Warszawa: WWF.

6. Brūmelis, G., \& Jankovska, I. (2013). Latvijā sastopamo Eiropas Savienības aizsargājamo meža biotopu apsaimniekošanas pasākumu pieredze Eiropā (European experience of management activities of European Union protected forest habitats in Latvia). Retrieved March 14, 2017, from: http://natprogramme.daba. gov.lv/upload/File/NATPROGR_literatura_meza_biotopu_apsaimn.pdf. (in Latvian).

7. Bumbura, M., Jaundzeme, V., Muižarāja, E., \& Pētersone, A. (1967). Augu morfoloğija un anatomija (The Morphology and Anatomy of Plants). Rīga: Zvaigzne. (in Latvian).

8. Ek, T., Suško, U., \& Auziņ̧̌̌, R. (2002). Mežaudžu atslēgas biotopu inventarizācija (Inventory of Woodland Key Habitats). Rīga. (in Latvian).

9. Ellenberg, H., Weber, H.E., Düll, R., Wirth, V., Werner, W., \& Paulißen, D. (1992). Zeigerwerte von Pflanzen in Mitteleuropa. Verlag Erich Goltze KG, Göttingen.

10. Gavrilova, G., \& Šulcs, V. (1999). Latvijas vaskulāro augu flora. Taksonu saraksts (Flora of Latvian Vascular Plants. List of Taxa). Latvijas Universitātes Biolog̣ijas institūts, Botānikas laboratorija, Rīga. (in Latvian).

11. Kenigsvalde, K., Arhipova, N., Laiviņš, M., \& Gaitnieks, T. (2010). Ošu audžu bojāeju izraisošā sēne Chalara fraxinea Latvijā (Ash grove death causing fungus Chalara fraxinea in Latvia). Mežzinātne, 21 (54), 110. - 120. lpp. (in Latvian).

12. Krampis, I. (2011). Boreālā un nemorālā bioma kokaugu sugu regionālā izplatība Latvijā (Regional distribution of boreal and nemoral biome woody plants species in Latvia). Rìga. (in Latvian). 
13. Laiviņš, M., Bambe, B., Rūsiņa, S., Piliksere, D., \& Kreile, V. (2008). Augu sugu sociologisko grupu ekologija un ǵeogrāfija Latvijas skujkoku mežos (Ecology and Geography of plant species sociological groups in Latvian coniferous forests). LLU raksti, 20 (315), 1. - 21. lpp. (in Latvian).

14. Laiviņš, M. (2014). Latvijas meža un krūmāju augu sabiedrības un biotopi (Communities of plants and forests' and shrub' habitats in Latvia). Mežzinātne, 28 (61), 6. - 38. lpp. (in Latvian).

15. Lassauce, A., Paillet, Y., Jactel, H., \& Bougat, C. (2011). Deadwood as surrogate for forest biodiversity: Meta - analysis of correlations between deadwood volume and species richness of saproxylic organisms. Ecological Indicators, Vol. 11., pp. 1027 - 1039. DOI: 10.1016/j.ecolind.2011.02.004.

16. Lārmanis, V., Priedītis, N., \& Rudzīte, M. (2000). Mežaudžu atslēgas biotopu rokasgrāmata (The manual of Woodland key habitats). Rīga: Valsts meža dienests, 127 lpp. (in Latvian).

17. Liepa, I. (1996). Pieauguma mācība (Increment studies). Jelgava: LLU. (in Latvian).

18. Liepa, I., Miezīte, O., Luguza, S., Šulcs, V., Straupe, I., Indriksons, A., Dreimanis, A., Saveljevs, A., Drēska, A., Sarmulis, Z., \& Dubrovskis, D. (2014). Meža tipologiija (Forest typology). Jelgava: studentu biedrība Šalkone, 118 lpp. (in Latvian).

19. Liepa, L., \& Straupe, I. (2012). The assesment of vegetation diversity in black alder woodland key habitats in Zemgale. In 18th international scientific conference Research for Rural Development, 16 - 18 May 2012 (Vol. 2, pp. $37-42$ ).

20. Madžule, L., Brūmelis, G., \& Tjarve, D. (2012). Structures determining bryophyte species richness in a managed forest landscape in boreo-nemoral Europe. Biodiversity Conservation, 21, pp. 437 - 450. DOI: 10.1007/s10531-011-0192-z.

21. Markovs, M. (1965). Vispārējā geobotānika (General geobotany). Rīga: Liesma. (in Latvian).

22. Meža nozares attīstības novērtējums 1990. - 2013. (Assessment of forest branch development). Retrieved March 14, 2017, from: https://www.zm.gov.lv/public/ck/files/ZM/mezhi/politikas_doki/1_Pielikums MSNP\%202020 061214.pdf. (in Latvian).

23. Mežaka, A. (2009). Epiphytic bryophyte and lichen ecology in Latvian deciduous forests. PhD Thesis, Riga.

24. Mueller-Dombois, D., \& Ellenberg, H. (1974). Aims and methods of vegetation ecology. New York: Wiley.

25. Neville, P., \& Bastrup-Birk, A. (2006). Biosoil Meža bioloğiskās daudzveidības novērtēšana (Assessment of forest biodiversity). VMD. (in Latvian).

26. Pautasso, M., Aas, G., Queloz, V., \& Holdenrieder, O. (2013). European ash (Fraxinus excelsior) dieback - A conservation biology challenge. Biological Conservation, 158, pp. 37 - 49. DOI: 10.1016/j. biocon.2012.08.026.

27. Priedītis, N. (1999). Latvijas mežs: daba un daudzveidība. Rīga: Pasaules dabas fonds. (in Latvian).

28. Stokland, N.J., Siitonen, J., \& Jonsson, B.G. (2012). Biodiversity in Dead Wood. New York: Cambridge University Press.

29. Suško, U. (1997). Latvijas dabiskie meži (Natural forests of Latvia). Latvija: WWF. (in Latvian).

30. Tabaka, L. (2001). Latvijas flora un veǵetācija: Zemgales geobotāniskais rajons (Latvia's flora and vegetation: geobotanical region of Zemgale). Rīga: Latvijas Universitāte. (in Latvian).

31. Timonen, J., Siitonen, J., Gustafsson, L., Kotiaho, J.S., Stokland, J.N., Sverdruo-Thygenson, A., \& Mönkkönen, M. (2010). Woodland key habitats in northern Europe: concepts, inventory and protection. Scandinavian Journal of Forest Research, 25, pp. 309 - 324. DOI: 10.1080/02827581.2010.497160.

32. Timonen, J. (2011). Woodland Key Habitats. A key to Effective Conseravtion of Forest Biodiversity? Jyväskylä: University of Jyväskylä.

33. Zunde, M. (1999). Mežainuma un koku sugu sastāva pārmaiņu dinamika un to galvenie ietekmējošie faktori Latvijas teritorijā (Dynamics of forest cover and replacing of tree species composition and the main influencing factors in the territory of Latvia). In Strods, H. (Eds.) Latvijas mežu vēsture līdz 1940. gadam (111. - 203. lpp.) Rīga: Pasaules Dabas Fonds. (in Latvian).

34. База данных Флора сосудистых растений Центральной России (Database of Flora of vascular plants of Central Russia). Retrieved February 27, 2017, from: http://www.impb.ru/eco/index.php. (in Russian). 